\title{
JUVENILE LUPUS, CMV INFECTION AND CARDIAC TAMPONADE: CASE REPORT
}

LEVI COELHO MAIA BARROS (UECE, FORTALEZA, CE, Brasil), MATHEUS EUGENIO DE SOUSA LIMA (UECE, FORTALEZA, CE, Brasil), ROSENY MARINHO MESQUITA PEREIRA (HOSPITAL INFANTIL ALBERT SABIN, FORTALEZA, CE, Brasil), WILLENE CAMPELO RABELO (HOSPITAL INFANTIL ALBERT SABIN, FORTALEZA, CE, Brasil), LIA ARCANJO ALVES VASCONCELOS (ESCOLA DE SAUDE PUBLICA DO CEARA, FORTALEZA, CE, Brasil)

\section{BACKGROUND}

Systemic lupus erythematosus (SLE) manifests itself in several body systems and usually presents in a severe form when in pediatric patients. One rare manifestation is a cardiac involvement, as cardiac tamponade, which can also be precipitated by infections, including the cytomegalovirus infection (CMV). We then present an unusual case of cardiac tamponade in a pediatric patient with SLE concurrent with $\mathrm{CMV}$ infection and its management.

\section{CASE REPORT}

A 9 years old female patient presented to the emergency department with respiratory depression, polyarthritis, fever and various cutaneous manifestations, evolving rapidly with a decrease in general condition, intense dyspnea, hypophonetic murmurs, jugular turgor, pericardial friction, hemodynamic instability and intense pallor. Doppler-echocardiogram showed a pericardial effusion, which was followed by a pericardiocentesis and pleuropericardial drainage in water seal, without intercurrences. We proceed the management with the fulfillment of SLE's criteria and positive serology and antigenemia for CMV, with titles of 15 / 200,000 cells. Medications for control of systemic disease and the viral infection were then iniciated and the patient evolved with good clinical response. After 32 days of IV gancyclovir, antigenemia for CMV was 1/200,000. She was discharged with oral valagancyclovir due to persistent positive antigenemia

\section{CONCLUSION}

Due to the broad clinical spectrum of SLE, medical professional must consider the diagnosis of SLE in cardiac tamponade, as well as considering the presence of CMV infections in this population, specially if patients were immunocompromised. Lack of data regarding the management of both symptomatic and assymptomatic concurrent SLE and CMV infection turns the association of this entities into a complex medical challange 